\title{
Deskripsi Pembelajaran Matematika Berbantuan Video Geogebra dan Pemahaman Matematis Siswa pada Materi Fungsi Kuadrat
}

\author{
Abdur Rochim ${ }^{1 *}$, Tutik Herawati ${ }^{2}$, Nurwiani $^{3}$ \\ SMK Muhammadiyah 1 Baron \\ Jalan Barat Pasar No. 27 Baron, Indonesia \\ 1*abdur.rochim88@gmail.com \\ MI Plus Darul Falah \\ Jalan Yos Sudarso No. 6 Komplek Masjid Darul Falah Mojoagung, Indonesia \\ 2tutuik.wati2@gmail.com \\ STKIP PGRI JOMBANG \\ Jalan Pattimura III/20 Jombang, Indonesia \\ 3nurwiani@gmail.com
}

Artikel diterima: 08-02-2021, direvisi: 23-05-2021, diterbitkan: 31-05-2021

\begin{abstract}
Abstrak
Penelitian ini bertujuan untuk mendeskripsikan proses pembelajaran matematika dengan media video Geogebra pada materi fungsi kuadrat dan mendeskripsikan pemahaman matematis siswa sebelum dan sesudah pemanfaatan media video Geogebra materi fungsi kuadrat. Penelitian ini merupakan penelitian deskriptif dengan menggunkan subjek penelitian kelas XI SMK Muhammadiyah 1 Baron berjumlah 11 siswa yang dipilih berdasarkan purposive sampling. Metode pengumpulan data dalam penelitian ini menggunakan teknik tes pemahaman matematis awal dan akhir serta teknik dokumentasi selama proses pembelajaran. Hasil penelitian menunjukkan bahwa proses pembelajaran matematika berbantuan media video Geogebra materi fungsi kuadrat dibagi menjadi 3 kegiatan yaitu pendahuluan, inti dan penutup. Hasil pemahaman matematis siswa sebelum dan sesudah pemanfaatan media video Geogebra materi fungsi kuadrat terdapat perbedaan yang cukup nyata yaitu dari pemahaman matematis awal sebesar $9 \%$ menjadi $45 \%$. Artinya 45\% siswa memenuhi semua indikator pemahaman matematis.

Kata Kunci: Pemahaman Matematis, Pembelajaran Matematika, Video Geogebra.

Description of Mathematics Learning Assisted by Geogebra Videos and Students' Mathematical Understanding on Quadratic Functions Material Abstract

This study aims to describe the mathematics learning process using Geogebra video media on quadratic functions material and to describe students' mathematical understanding before and after the use of Geogebra video media with quadratic functions material. This research is a descriptive study using the research subjects of class XI SMK Muhammadiyah 1 Baron totaling 11 students who were selected based on purposive sampling. The data collection method in this study used the initial and final mathematical comprehension test techniques and documentation techniques during the learning process. The results showed that in the learning process of mathematics assisted by Geogebra video media, the quadratic function material was divided into 3 activities, namely introduction, core, and closing. The results of students' mathematical understanding before and after the use of Geogebra video media with the quadratic function material there were quite differences, namely from the initial mathematical understanding of $9 \%$ to $45 \%$. This means that $45 \%$ of students meet all indicators of mathematical understanding.

Keywords: Mathematical Comprehension, Mathematics Learning, Geogebra Video.
\end{abstract}




\section{Pendahuluan}

Pembelajaran merupakan suatu interaksi antara peserta didik, pendidik dan sumber belajar. Matematika sebagai ilmu yang tersusun teratur dalam berbagai struktur dan hierarkinya masing-masing mempunyai karakteristik atau ciri-ciri khusus. Karakteristik tersebut menurut Soejadi (2007) adalah sebagai berikut: (1) Matematika memiliki objek kajian yang abstrak (hanya ada dipikiran) (2) Bertumpu pada kesepakatan (lebih bertumpu pada aksioma formal), (3) Berpola pikir deduktif, (4) Konsisten dalam sistemnya, (5) Memiliki/menggunakan simbol yang kosong dari arti, (6) Memperhatikan semesta pembicaraan.

Pembelajaran matematika berlandaskan filsafat kontruktivisme artinya bahwa pengetahuan tidak bisa ditransfer dari yang mengetahui (pendidik) kepada si pembelajar (peserta didik). Pengetahuan yang dimiliki seseorang adalah bentukan/ kontruksi dari individu sendiri dalam mengkonstruksi pengetahuan itu pembelajar haruslah aktif baik secara fisik ataupun mental (Ma'rufi, 2015).

Dalam rangka mencapai tujuan pembelajaran matematika, sekolah di Indonesia telah menerapkan Kurikulum 2013. Selain itu beberapa peneliti menerapkan model pembelajaran yang dalam mencapai tujuan pembelajaran diantaranya Tristanti (2017), Tristanti dan Rakhmawati (2017), Purwandari, Ekawati, \& Tristanti (2020), Tristanti \& Hidayati (2020), dan Tristanti, Akbar, \& Rahayu (2021).

Salah satu tujuan pembelajaran matematika yang tertuang dalam Permendikbud Nomor 22 Tahun 2016 adalah memahami konsep matematika, mendeskripsikan bagaimana keterkaitan antar konsep matematika dan menerapkan konsep atau logaritma secara efisien, luwes, akurat, dan tepat dalam memecahkan masalah. Pemahaman matematis (Mathematical Understanding) adalah kemampuan matematis yang esensial dan haruslah dimiliki siswa didalam belajar matematika.

Pentingnya mempunyai kemampuan pemahaman matematis adalah bahwa kemampuan tersebut termuat dalam kurikulum 2013. Hal ini sesuai dengan UU No. 24 Tahun 2016 tentang KI/KD pada pendidikan dasar dan menengah, kemudian untuk SMK/MAK tertuang dalam Perdirjen No.464 tahun 2018 bahwa tujuan kurikulum pada SMK/MAK pada aspek pengetahuan adalah Memahami, menerapkan, dan menganalisis, serta mengevaluasi tentang pengetahuan faktual, konseptual, operasional dasar, dan metakognitif sesuai bidang dan lingkup kajian matematika pada tingkat teknis, spesifik, detil, dan kompleks, serta berkenaan dengan ilmu pengetahuan, teknologi, seni, budaya, dan humaniora dalam konteks pengembangan potensi diri dan sebagai bagian dari keluarga, sekolah, dunia kerja, warga masyarakat nasional dan regional, juga internasional.

Pemahaman matematis juga penting dimiliki oleh siswa. Hal ini sesuai dengan pendapat Santrock (Hendriana, Rohaeti dan Sumarmo, 2017) bahwa pemahamn konsep adalah kunci dari pembelajaran. Demikian juga pemahaman matematis adalah landasan untuk berpikir dalam menyelesaikan persoalan-persoalan matematika maupun masalah kehidupan 
nyata. Selain itu juga kemampuan pemahaman matematis mendukung pada pengembangan kemampuan matematis lainnya, seperti kemampuan komunikasi, kemampuan pemecahan masalah, penalaran, koneksi, representasi, berpikir kritis dan kreatif.

Peneliti memberikan tes untuk mendeskripsikan pemahaman matematis siswa pada materi fungsi kuadrat. Berikut tes permasalahan yang diberikan kepada siswa disajikan pada Gambar 1 berikut.

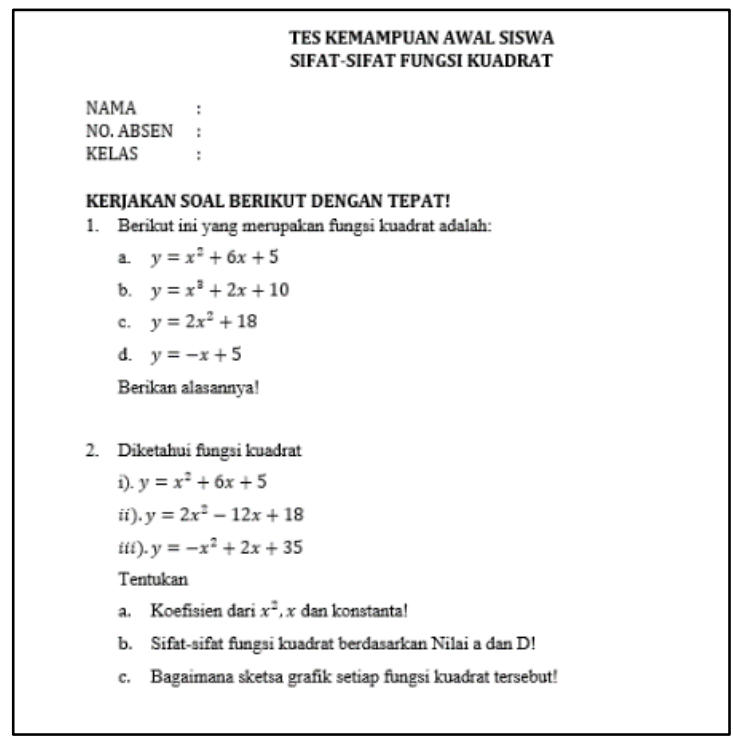

Gambar 1. Tes Pemahaman Matematis Siswa

Permasalahan yang terjadi di sekolah terlihat pada hasil pretes disajikan pada Gambar 2 berikut.

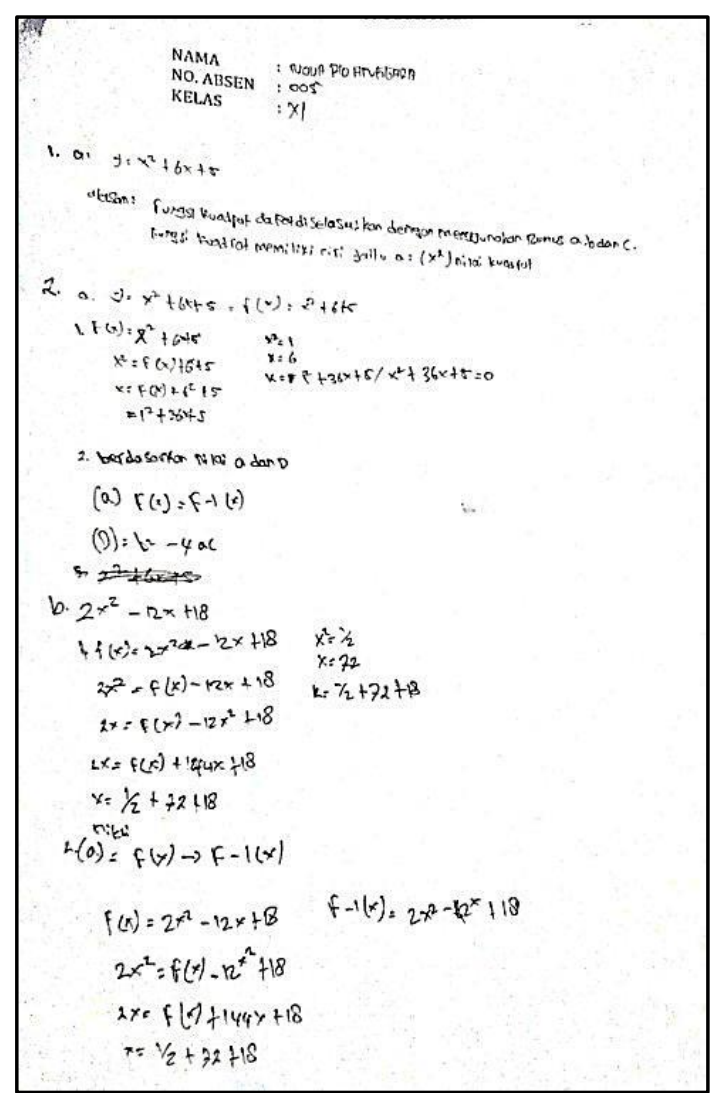

Gambar 2. Contoh Pekerjaan Siswa

Dari hasil tes awal bisa diketahui Permasalahan yang dialami siswa SMK Muhammadiyah 1 Baron kelas $X$ adalah mengidentifikasi dan membuat contoh dan bukan contoh, menggunakan simbol-simbol untuk mempresentasikan suatu konsep, mengidentifikasi sifat - sifat suatu konsep dan mengenal syarat yang menentukan suatu konsep, mengenal berbagai makna dan interpretasi konsep, membandingkan dan membedakan konsep. Dengan kata lain rendahnya pemahamaan siswa terhadap materi fungsi kuadarat. Oleh karena itu, perlu adanya perbaikan proses pembelajaran dengan memaksimalkan teknologi dan media pembelajaran serta untuk memotivasi belajar siswa, baik motivasi instrinsik maupun ekstrinsik agar pemahaman matematis siswa lebih tinggi. 
Salah satu media pembelajaran yang berupa aplikasi program komputer yang dimanfaatkan dalam pembelajaran matematika adalah Geogebra. Geogebra merupakan program dinamis yang mempunyai fasilitas untuk memvisualisasikan atau mendemonstrasikan banyak konsep matematika, serta sebagai alat yang membantu untuk mengkonstruksi konsepkonsep matematika (Syahbana, 2016).

Menurut Hohenwarter dan Fuchs (2004) Geogebra adalah alat yang sangat serbaguna untuk pendidikan matematika di sekolah menengah. Dalam pembelajaran matematika geogebra memiliki beberapa fungsi antara lain (1) Geogebra sebagai alat demonstrasi dan visualisasi, yaitu geogebra merupakan perangkat lunak dengan cakupan yang luas karena representasi yang berbeda. (2) Geogebra sebagai alat konstruksi, yaitu geogebra memiliki semua kemampuan yang dibutuhkan dari perangkat lunak menggambar / mendesain yang sesuai. (3) Geogebra untuk menemukan matematika, yaitu geogebra dapat digunakan sebagai alat penting untuk pembelajaran yang membantu menciptakan suasana yang sesuai untuk belajar. (4) Geogebra untuk mempersiapkan bahan ajar, yaitu geogebra mendorong para guru untuk mempersiapkan materi untuk proses pengajaran menggunakannya sebagai alat kerjasama, komunikasi dan representasi serta memberi guru lebih banyak waktu untuk berkonsentrasi pada ide-ide dasar dan penalaran matematika.

Berdasarkan hasil penelitian Briggs, Wilkinson, \& Golash (2014) dan Octamela, Suweken, \& Ardana (2019) bahwa aplikasi geogebra dapat menjadi salah satu alternatif multimedia yang sangat efektif dalam memberikan infomasi. Aplikasi Geogebra memberikan kesempatan yang efektif untuk mengkreasi belajar secara online interaktif yang memungkinkan siswa untuk mengeksplorasi berbagai konsep matematika. Hal tersebut sesuai dengan hasil penelitian Aizikovitsh-Udi (2011) bahwa visualisasi dinamis yang dimiliki apilkasi geogebra dapat meningkatkan pemahaman siswa dalam mempelajari konsep-konsep matematika

Pada penelitian ini, peneliti ingin mendeskripsikan proses pembelajaran matematika berbantuan video Geogebra dan pemahaman matematis siswa khususnya pada materi fungsi kuadrat. Media pembelajaran berbantuan video Geogebra dalam penelitian ini dibuat dalm bentuk vidio pembelajaran sehingga siswa lebih mudah melihat dan memahami secara berulang-ulang. Kelebihan Media Pembelajaran berbentuk video adalah (1) Video dapat melengkapi pengalamanpengalamn dasar siswa ketika membaca dan berpraktik. (2) Video menggambarkan proses yang tepat dan dapat disaksikanatau dilihat secara berulang-ulang. (3) Video dapat mendorong dan meningkatkan motivasi serta menanamkan sikap afektif siswa (4) video yang memuat nilai positif dapat mengundang pemikiran dan pembahasan oleh kelompok. Video pembelajaran ini bisa dibuka dan dilihat pada chanel youtube dengan alamat https://www.youtube.com/watch?v=jPTf6 MBK8dY\&t=649s. 


\section{Metode}

Penelitian ini mendeskripsikan kejadiankejadian yang menjadi pusat perhatian pada saat proses pembelajaran matematika berbantuan video geogebra dalam materi fungsi kuadrat serta hasil pemahaman matematis siswa sebelum dan setelah proses pembelajaran dengan menggunakan media tersebut. Peneliti menggunakan metode deskriptif untuk mendapatkan informasi tentang bagaimana proses pembelajaran matematika menggunakan media pembelajaran video geogebra dan pemahaman matematis siswa pada materi fungsi kuadrat yang dilaksanakan dua kali pembelajaran dalam waktu yang berbeda.Video geogebra juga diputar untuk dua kali proses pembelajaran, sekali secara klasikal dan dilanjutkan oleh masing-masing kelompok untuk setiap pertemuan.

Penelitian ini dilaksanakan di SMK Muhammadiyah 1 Baron, karena latar belakang peneliti menemukan permasalahan saat melaksanakan pembelajaran matematika di SMK Muhammdiyah 1 Baron. Penelitian dilaksanakan pada siswa kelas XI semester ganjil tahun pelajaran 2020/ 2001.

Metode pengumpulan data yang digunakan dalam penelitian ini menggunakan metode tes dan dokumentasi. Tes yang digunakan dalam penelitian ini adalah tes pemahaman matematis awal dan akhir berbentuk subjektif/uraian. Tes pemahaman matematis berbentuk subjektif ini berisi masalah yang membutuhkan langkahlangkah atau tahapan penyelesaian. Oleh karena itu dalam setiap langkah penyelesaian mendeskripsikan pemahaman matematis siswa. Dokumentasi dalam penelitian ini dokumentasinya berupa foto, video dan catatan-catatan yang diperoleh pada saat pelaksanaan pembelajaran matematika dan tes pemahaman matematis awal dan akhir siswa di kelas.

Instrumen yang digunakan dalam penelitian ini adalah instrumen utama yaitu peneliti sendiri dan instrumen pendukung yaitu lembar tes pemahman matematis awal dan akhir yang berbeda serta masingmasing berjumlah dua soal yang telah divalidasi oleh Guru senior dan Dosen ahli. Instrumen pendukung lainnya yaitu dokumentasi foto, audio dan video selama proses pembelajaran dan pengerjaan tes Pemahaman matematis yang memenuhi indikator pemahaman matematis seperti pada Tabel 1.

Tabel 1.

Tabel Indikator Pemahaman Matematis Siswa

\begin{tabular}{|c|c|}
\hline $\begin{array}{c}\text { Kemampuan } \\
\text { Siswa }\end{array}$ & Indikator \\
\hline \multirow[t]{5}{*}{$\begin{array}{l}\text { Pemahaman } \\
\text { Matematis }\end{array}$} & $\begin{array}{l}\text { Subjek mengidentifikasi dan } \\
\text { membuat contoh dan bukan } \\
\text { contoh fungsi kuadrat. }\end{array}$ \\
\hline & $\begin{array}{lr}\text { Subjek menggunakan } & \text { simbol- } \\
\text { simbol } & \text { untuk } \\
\text { mempresentasikan } & \text { konsep } \\
\text { fungsi kuadrat. } & \\
\end{array}$ \\
\hline & \begin{tabular}{lr} 
Subjek mengidentifikasi sifat- & \multicolumn{1}{c}{ m } \\
sifat konsep fungsi kuadrat dan \\
mengenal syarat yang \\
menentukan konsep fungsi \\
kuadrat.
\end{tabular} \\
\hline & $\begin{array}{l}\text { Subjek mengenal berbagai } \\
\text { makna dan interpretasi konsep } \\
\text { fungsi kuadrat }\end{array}$ \\
\hline & $\begin{array}{l}\text { Subjek membandingkan dan } \\
\text { membedakan konsep fungsi } \\
\text { kuadrat. }\end{array}$ \\
\hline
\end{tabular}




\section{Hasil dan Pembahasan}

Kegiatan penelitian ini dilaksanakan pada tanggal 18 November 2020 untuk melaksanakan tes pemahaman matematis awal siswa, dilanjutkan tanggal 25 November 2020 untuk melakukan proses pembelajran berbantuan video geogebra dengan materi definisi fungsi kuadrat dan sifat fungsi kuadrat berdasarkan koefisien $x^{2}$. Pada tanggal 26 November 2020 dilakukan pembelajaran kedua dengan materi sifar grafik fungsi kuadrat berdasarkan nilai Diskriminan. Kegiatan terkahir tanggal 02 Desemeber 2020 yaitu melakukan tes pemahaman matematis akhir siswa.

Deskripsi proses pembelajaran matematika berbantuan video geogebra pada materi fungsi kuadrat dalam kedua pertemuan tersebut memenuhi indikator pada Tabel 2.

Tabel 2.

Indikator Proses Pembelajaran

\begin{tabular}{|c|c|}
\hline $\begin{array}{c}\text { Proses } \\
\text { Pembelajaran }\end{array}$ & Indikator \\
\hline \multirow[t]{4}{*}{ Pendahuluan } & $\begin{array}{l}\text { Guru Membuka proses } \\
\text { Pembelajaran dengan berdoa dan } \\
\text { Menyampaikan salam }\end{array}$ \\
\hline & Guru Mengecek kehadiran siswa \\
\hline & $\begin{array}{l}\text { Guru Memberikan apersepsi dan } \\
\text { Motivasi }\end{array}$ \\
\hline & $\begin{array}{l}\text { Guru Menyampaiakan Tujuan } \\
\text { Pembelajaran dan kegiatan yang } \\
\text { akan dilakukan }\end{array}$ \\
\hline \multirow[t]{5}{*}{ Inti } & $\begin{array}{l}\text { Guru Membagi kelompok belajar } \\
\text { dan LKPD }\end{array}$ \\
\hline & $\begin{array}{l}\text { Guru Menjelaskan materi sifat-sifat } \\
\text { fungsi kuadrat berbantuan } \\
\text { geogebra melalui video }\end{array}$ \\
\hline & $\begin{array}{l}\text { Siswa Menyelesaikan masalah pada } \\
\text { LKPD dengan bantuan Sofware } \\
\text { Geogebra }\end{array}$ \\
\hline & $\begin{array}{l}\text { Siswa Mempresentasikan hasil } \\
\text { LKPD }\end{array}$ \\
\hline & $\begin{array}{l}\text { Guru melibatkan siswa } \\
\text { mengevaluasi jawaban hasil diskusi } \\
\text { presentasi kelompok. }\end{array}$ \\
\hline
\end{tabular}

Penutup

Guru bersama siswa melakukan refleksi dan kesimpulan terhadap hasil pembelajaran

Guru memberikan tugas mandiri terstruktur dan dikumpulkan pada pertemuan berikutnya

Guru mengakhiri kegiatan belajar dengan memberikan pesan untuk mempelajari materi selanjutnya

Proses pembelajaran berbantuan geogebra dideskripsikan sebagai berikut. Pada kegiatan pendahuluan, aktivitas pembelajarannya adalah Guru memulai proses pembelajaran dengan mengucapkan salam dan berdoa bersama serta menyertakan konsep pengamalan ajaran agama yang dianut; Guru mengecek kehadiran peserta didik dan menanyakan kabar hari ini; Guru memberikan apersepsi tentang materi sifat-sifat grafik fungsi kuadrat yaitu apa pengertian fungsi kuadrat dan seperti apa grafinya yang telah dipelajari saat SMP; Guru memberikan gambaran tentang pentingnya memahami fungsi kuadart dan memberikan gambaran tentang penerapannya dalam kehidupan sehari-hari; Guru menyampaikan tujuan pembelajaran yang ingin dicapai yaitu Setelah berdiskusi dan Pemberian LKPD, siswa dapat Menemukan sifat-sifat grafik fungsi kuadrat serta menggambar sketsa grafik fungsi kuadrat. Pada kegitan inti, aktivitas pembelajarannya adalah Guru membentuk kelompok heterogen terdiri dari 2 siswa; Guru membagikan Lembar Kerja Peserta Didik (LKPD) yang berisikan masalah serta meminta peserta didik berkolaborasi untuk menyelesaikan masalah; Guru membagikan link video mengenai materi fungsi kuadrat kepada setiap kelompok. Setiap kelompok mengamati atau melihat sekali secara 
klasikal dan bisa dilanjutkan mengamati dan membuka video secara berulang-ulang sampai adanya pemahaman dalam kelompok tersebut. Link vdeo pembelajaran berbantuan video geogebra adalah:

https://www.youtube.com/watch?v=jPTf6 MBK8dY\&t=649s; Dengan bantuan media video Geogebra, peserta didik mengidentifikasi masalah yang berkaitan dengan konsep sifat-sifat grafik fungsi kuadrat. Peserta didik berdiskusi tentang materi sifat-sifat grafik fungsi kuadrat. Guru memberikan scafolding/bantuan seperlunya untuk setiap kelompok; Salah satu kelompok mempresentasikan hasil diskusinya untuk setiap masalah pada LKPD. Dan kelompok yang lain menanggapi hasil persentasi; Guru melibatkan peserta didik mengevaluasi jawaban hasil diskusi kelompok penyaji serta masukan dari peserta didik yang lain dan membuat kesepakatan, bila jawaban yang disampaikan peserta diidk sudah benar. Dengan tanya jawab dengan siswa, guru mengarahkan semua siswa pada simpulan mengenai permasalahan tersebut. Pada kegiatan penutup, kegiatan pembelajarannya adalah melakukan refleksi dan kesimpulan terhadap hasil pembelajaran fungsi kuadrat oleh guru dan siswa, Guru memberikan tugas mandiri terstruktur tentang fungsi kuadrat yang akan dikumpulkan pada pertemuan selanjutnya, serta Guru mengakhiri pembelajaran materi fungsi kuadrat dengan memberikan pesan kepada peserta didik untuk mempelajari materi selanjutnya.

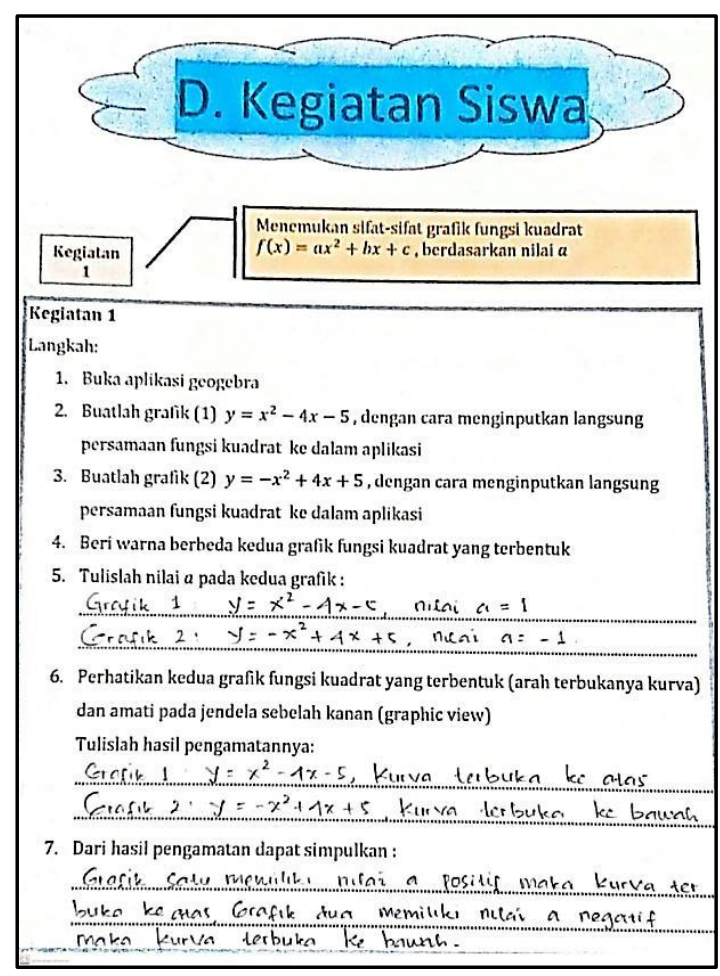

Gambar 3. Contoh Hasil LKPD Siswa pada Pembelajaran Pertama.

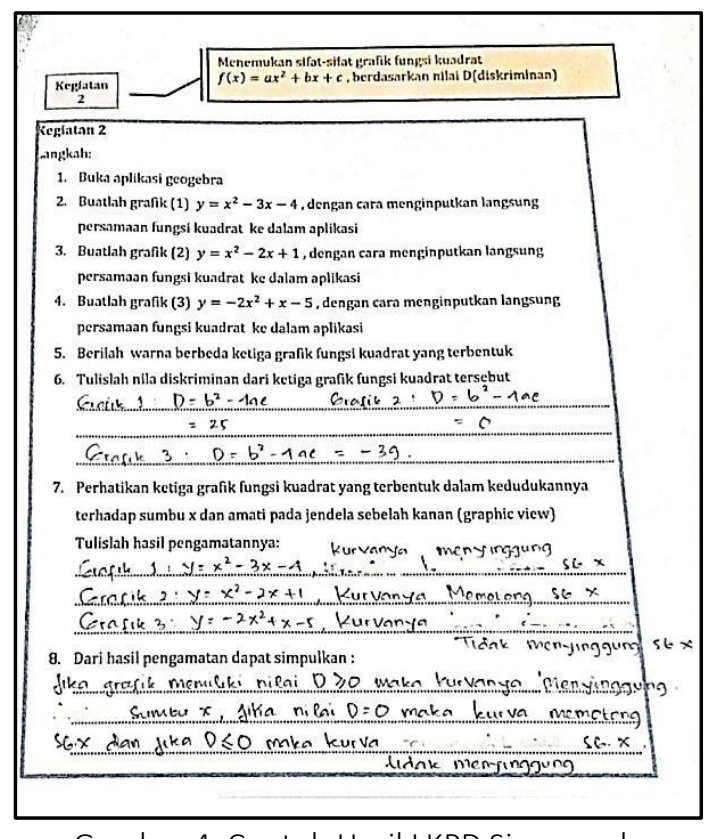

Gambar 4. Contoh Hasil LKPD Siswa pada Pembelajaran Kedua.

Hasil Kerja siswa pada tes pemahaman matematis awal dan akhir siswa disajikan pada Tabel 3 dan Tabel 4. 
Tabel 3.

Hasil Kerja Siswa pada Tes Pemahaman Awal Siswa

\begin{tabular}{|c|c|c|}
\hline No & Tes Pemahaman Matematis Awal & Hasil Kerja Siswa \\
\hline 1 & $\begin{array}{l}\text { Berikut ini yang merupakan fungsi } \\
\text { kuadrat adalah: } \\
\text { a. } y=x^{2}+6 x+5 \\
\text { b. } y=x^{3}+2 x+10 \\
\text { c. } y=2 x^{2}+18 \\
\text { d. } y=-x+5 \\
\text { Berikan alasannya! }\end{array}$ & $\begin{array}{c}\text { Seluruh siswa (11 Siswa) menjawab dengan benar. } \\
\text { Seluruh siswa mengidentifikasi contoh dan bukan contoh fungsi } \\
\text { kuadrat serta memberikan alsasan yang tepat bahwa fungsi yang } \\
\text { dipilih adalah fungsi kuadrat. Seluruh siswa memilih yang } \\
\text { merupakan fungsi kuadrat adalah poin (a) dan poin (c) dengan } \\
\text { alasan bahwa fungsi tersebut memiliki derajat/pangkat tertinggi } \\
\text { adalah dua. }\end{array}$ \\
\hline \multirow[t]{5}{*}{2} & $\begin{array}{l}\text { Diketahui fungsi kuadrat } \\
\begin{array}{l}\text { i). } y=x^{2}+6 x+5 \\
\text { ii) } y=2 x^{2}-12 x+18 \\
\text { iii). } y=-x^{2}+2 x+35 \\
\text { Tentukan: }\end{array}\end{array}$ & \\
\hline & $\begin{array}{l}\text { a. Koefisien dari } x^{2}, x \text { dan } \\
\text { konstanta! }\end{array}$ & $\begin{array}{l}\text { Enam siswa menjawab dengan benar sedangkan lima siswa } \\
\text { masih salah dalam menjawab. } \\
\text { Siswa yang menjawab dengan benar berarti menggunakan } \\
\text { simbol matemaika untuk mempresentasikan suatu konsep } \\
\text { koefisien dan konstanta fungsi kuadrat dengan tepat yaitu } \\
\text { menentukan nilai } a, b \text {, dan } c \text { dari tiga fungsi kuadrat yang } \\
\text { diberikan. } \\
\text { Lima siswa yang salah dalam menjawab dibedakan dua yaitu tiga } \\
\text { siswa yang tidak menjawab dan dua siswa menjawab tetapi } \\
\text { kurang tepat. } \\
\text { Siswa yang salah dalam menjawab berarti tidak menggunakan } \\
\text { simbol matematis untuk mempresentasikan suatu konsep } \\
\text { koefisien dan konstanta fungsi kuadrat dengan benar. }\end{array}$ \\
\hline & $\begin{array}{c}\text { b. Sifat-sifat fungsi kuadrat } \\
\text { tersebut! }\end{array}$ & $\begin{array}{l}\text { Satu siswa menjawab dengan benar dan } 10 \text { siswa menjawab } \\
\text { dengan salah. } \\
10 \text { siswa yang salah dalam menjawab dibedakan menjadi dua } \\
\text { yaitu empat siswa yang tidak menjawab dan enam siswa yang } \\
\text { menjawab tapi salah. } \\
10 \text { siswa tersebut tidak tepat dalam Mengidentifikasi sifat-sifat } \\
\text { konsep dan mengenal syarat yang menentukan konsep fungsi } \\
\text { kuadrat berdasarkan nilai } a \text { dan } D \text { (diskriminan). } \\
\text { Para siswa tersebut tidak menentukan nilai } a \text { dan } D \text { dengan } \\
\text { tepat, tidak menentukan jika nilai } a>0 \text { atau } a<0 \text { apakah } \\
\text { grafik fungsi kuadrat terbuka keatas atau kebawah, serta tidak } \\
\text { menentukan jika nilai } D>0, D=0 \text { atau } D<0 \text { itu apakah } \\
\text { memotong sumbu } x, \text { menyinggung sumbu x ataukah tidak } \\
\text { memotong dan tidak meyinggung sumbu x. }\end{array}$ \\
\hline & $\begin{array}{c}\text { c. Bagaimana sketsa grafik setiap } \\
\text { fungsi kuadrat tersebut! }\end{array}$ & $\begin{array}{c}\text { Satu siswa menjawab dengan benar dan } 10 \text { siswa menjawab } \\
\text { dengan salah. } \\
10 \text { siswa yang salah dalam menjawab karena tidak dijawab. } \\
\text { Siswa tersebut salah dalam menjawab dikarenakan tidak } \\
\text { Mengenal berbagai makna dan interpretasi konsep fungsi } \\
\text { kuadrat. } \\
\text { Makna dan Interpretasi fungsi kuadrat dalam hal ini adalah } \\
\text { membuat sketsa grafik kuadrat. Minimal tiga langkah yang harus } \\
\text { dicari yaitu menentukan titik potong terhadap sumbu koordinat, } \\
\text { menentukan titik puncak serta membuat sketsa grafik dengan } \\
\text { cara menghubungkan titik potong dan titik puncak. }\end{array}$ \\
\hline & & $\begin{array}{l}\text { Dari empat pertanyaan yang sudah diberikan terdapat satu siswa } \\
\text { (9\%) yang menjawab semua pertanyaan dengan benar. Artinya } \\
\text { siswa tersebut membandingkan dan membedakan konsep fungsi }\end{array}$ \\
\hline
\end{tabular}




\begin{tabular}{|c|c|}
\hline $\begin{array}{c}\text { kuadrat dengan tepat. Sedangkan } 10 \text { siswa (91\%) lainnya salah } \\
\text { dalam membedakan dan membandingkan konsep fungsi } \\
\text { kuadrat. }\end{array}$ \\
\hline Kesimpulan & $\begin{array}{r}\text { Terdapat 9\% siswa yang memiliki pemahaman matematis utuh } \\
\text { tentang sifat-sifat fungsi kuadrat yang memenuhi semua } \\
\text { indikator pemahaman matematis pada tes awal. }\end{array}$ \\
\hline
\end{tabular}

Tabel 4.

Hasil Kerja Siswa pada Tes Pemahaman Akhir Siswa.

\begin{tabular}{|c|c|c|}
\hline No & $\begin{array}{l}\text { Tes Pemahaman } \\
\text { Matematis Akhir }\end{array}$ & Hasil Kerja Siswa \\
\hline 1 & $\begin{array}{c}\text { Berikut ini yang } \\
\text { merupakan fungsi } \\
\text { kuadrat adalah: } \\
\text { a. } y=x^{2}+7 x+6 \\
\text { b. } y=x^{3}-2 x-25 \\
\text { c. } y=2 x^{2}-8 \\
\text { d. } y=-x+10 \\
\text { Berikan alasannya! }\end{array}$ & $\begin{array}{l}\text { Seluruh siswa (11 Siswa) menjawab dengan benar. } \\
\text { Seluruh siswa mengidentifikasi contoh dan bukan contoh fungsi kuadrat } \\
\text { serta memberikan alsasan yang tepat bahwa fungsi yang dipilih adalah } \\
\text { fungsi kuadrat. Seluruh siswa memilih yang merupakan fungsi kuadrat } \\
\text { adalah poin (a) dan poin (c) dengan alasan bahwa fungsi tersebut } \\
\text { memiliki derajat/pangkat tertinggi adalah dua. }\end{array}$ \\
\hline \multirow[t]{5}{*}{2} & $\begin{array}{l}\text { Diketahui fungsi kuadrat } \\
\begin{array}{l}\text { i). } y=x^{2}+7 x+6 \\
\text { ii). } y=2 x^{2}-8 x+8 \\
\text { iii). } y \\
=-x^{2}+7 x-10 \\
\quad \text { Tentukan }\end{array}\end{array}$ & \\
\hline & $\begin{array}{l}\text { a. Koefisien dari } x^{2}, x \\
\text { dan konstanta! }\end{array}$ & $\begin{array}{l}10 \text { siswa menjawab dengan benar sedangkan satu siswa masih salah } \\
\text { dalam menjawab. } \\
\text { Siswa yang menjawab dengan benar berarti menggunakan simbol-simbol } \\
\text { matematika untuk mempresentasikan konsep koefisien dan konstanta } \\
\text { fungsi kuadrat dengan tepat yaitu menentukan nilai } a, b \text {, dan } c \text { dari tiga } \\
\text { fungsi kuadrat yang diberikan. } \\
\text { Satu Siswa yang salah dalam menjawab karena tidak menggunakan } \\
\text { simbol matematis untuk mempresentasikan suatu konsep koefisien dan } \\
\text { konstanta fungsi kuadrat dengan benar. }\end{array}$ \\
\hline & $\begin{array}{l}\text { b. Sifat-sifat fungsi } \\
\text { kuadrat tersebut! }\end{array}$ & $\begin{array}{l}\text { enam siswa menjawab d benar dan lima siswa menjawab salah. } \\
\text { lima siswa tersebut tidak tepat dalam Mengidentifikasi sifat-sifat konsep } \\
\text { dan mengenal syarat yang menentukan konsep fungsi kuadrat } \\
\text { berdasarkan nilai } a \text { dan } D \text { (diskriminan). } \\
\text { Para siswa tersebut tidak menentukan nilai } a \text { dan } D \text { dengan tepat, tidak } \\
\text { menentukan jika nilai } a>0 \text { atau } a<0 \text { apakah grafik fungsi kuadrat } \\
\text { terbuka keatas atau kebawah, serta tidak menentukan jika nilai } D> \\
0, D=0 \text { atau } D<0 \text { itu apakah memotong sumbu } x \text {, menyinggung } \\
\text { sumbu x ataukah tidak memotong dan tidak meyinggung sumbu x. }\end{array}$ \\
\hline & $\begin{array}{l}\text { c. Bagaimana sketsa } \\
\text { grafik setiap fungsi } \\
\text { kuadrat tersebut! }\end{array}$ & $\begin{array}{l}\text { lima siswa menjawab dengan benar dan enam siswa menjawab dengan } \\
\text { salah. } \\
\text { Enam Siswa tersebut salah dalam menjawab dikarenakan tidak } \\
\text { Mengenal berbagai makna dan interpretasi konsep fungsi kuadrat. } \\
\text { Makna dan Interpretasi fungsi kuadrat dalam hal ini adalah membuat } \\
\text { sketsa grafik kuadrat. Minimal tiga langkah yang harus dicari yaitu } \\
\text { menentukan titik potong terhadap sumbu koordinat, menentukan titik } \\
\text { puncak serta membuat sketsa grafik dengan cara menghubungkan titik } \\
\text { potong dan titik puncak. }\end{array}$ \\
\hline & & Dari empat pertanyaan yang sudah diberikan terdapat lima siswa (45\%) \\
\hline
\end{tabular}




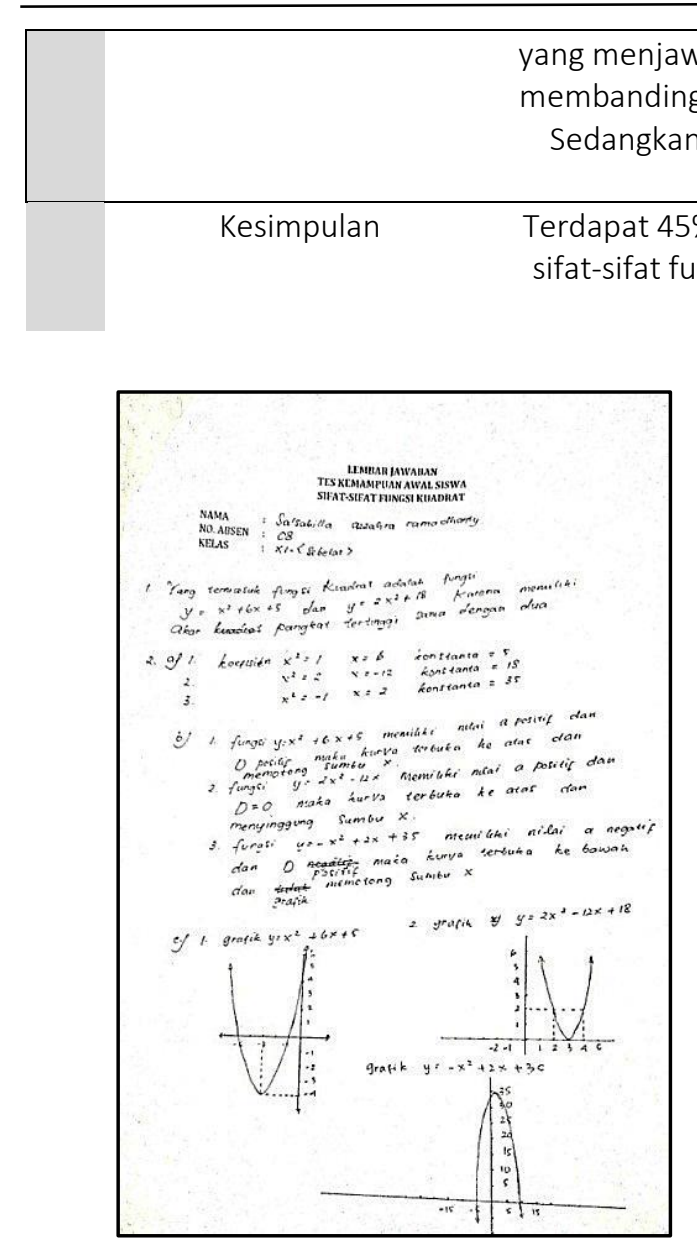

Gambar 5. Contoh Hasil Tes Pemahaman Matematis Awal Siswa.

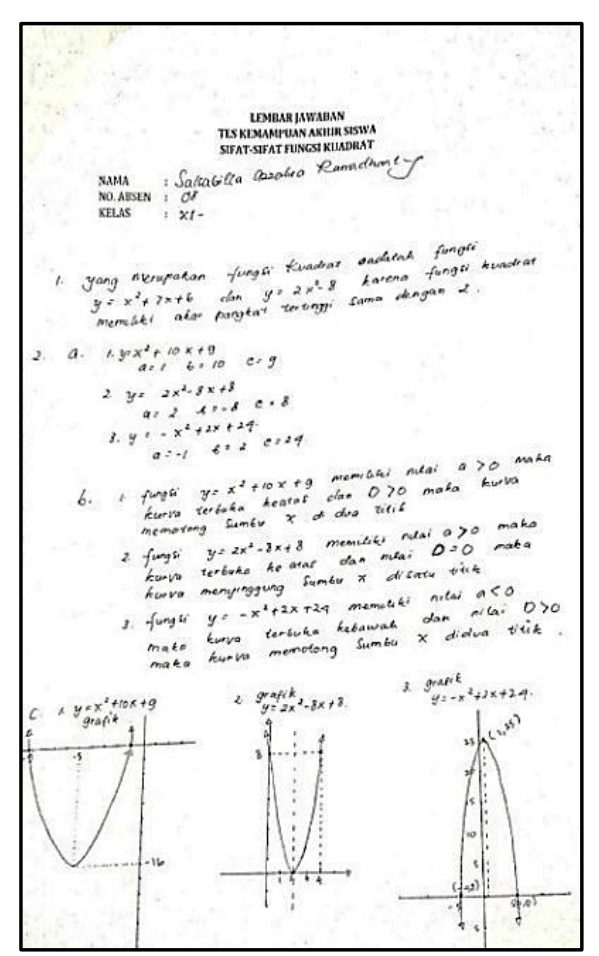

Gambar 6. Contoh Hasil Tes Pemahaman Matematis Akhir Siswa
Hasil pemahaman matematis siswa setelah pembelajaran matematika berbantuan video geogebra pada materi fungsi kuadrat adalah seluruh siswa mengidentifikasi contoh dan bukan contoh fungsi kuadrat serta memberikan alasan yang tepat bahwa fungsi yang dipilih adalah fungsi kuadrat, 10 dari 11 siswa menggunakan simbol-simbol matematika untuk mempresentasikan suatu konsep koefisien dan konstanta fungsi kuadrat dengan tepat yaitu menentukan nilai $a, b$, dan $c$ dari tiga fungsi kuadrat yang diberikan. Sebanyak 6 siswa mengidentifikasi sifat-sifat suatu konsep dan mengenal syarat yang menentukan konsep fungsi kuadrat berdasarkan nilai $a$ dan D (diskriminan). Ada 5 siswa yang mengenal berbagai makna dan interpretasi konsep fungsi kuadrat.

Berdasarkan hasil penelitian ini dapat dinyatakan bahwa pembelajaran matematika berbantuan geogebra dapat digunakan sebagai salah satu alternatif dalam mengembangkan pemahaman matematis siswa. Hal tersebut sesuai dengan hasil penelitian Briggs, Wilkinson, \& Golash (2014) dan Octamela, Suweken, \& Ardana (2019) bahwa aplikasi geogebra bisa menjadi salah satu pilihan multimedia yang efektif.

Aplikasi media Geogebra memberikan kesempatan atau pilihan yang efektif dalam melakukan kreasi dan inovasi pembelajaran online interaktif yang memungkinkan 
siswa dalam mencoba/mengeksplorasi konsep-konsep matematika. Hal tersebut sesuai dengan hasil dalam penelitian Aizikovitsh-Udi (2011) bahwa visualisasi dinamis pada geogebra bisa meningkatkan pemahaman siswa ketika mempelajari suatu konsep matematika.

Namun menurut pendapat Payne, Goodson, Tahim, Wharrad, \& Fan (2012), media geogebra memiliki keterbatasan yaitu media ini hanya bisa digunakan oleh siswa yang memiliki iPad atau laptop dengan merk Apple. Oleh karena itu, tidak semua siswa bisa menggunakan aplikasi geogebra. Hal ini juga dialami peneliti saat membuat media pembelajaran berbantuan geogebra dalam bentuk video pada materi fungsi kuadrat. Kendala tersebut meliputi: (1) Suara yang harus menyesuaikan dengan teks yang ada pada video, (2) Suara yang harus jelas, (3) Ukuran File yang terlalu kecil berdampak pada kejelasan pada tulisan yang ada pada video, (4) Ketika menggunakan HP android teks/tulisan kurang terlihat jelas (5) Peneliti tidak bisa mengetahui siswa melihat atau mendownload video secara penuh karena video tersebut terapload di youtube.

\section{Penutup}

Proses pembelajaran matematika berbantuan media Geogebra yang divideokan (Link youtube:

https://www.youtube.com/watch?v=jPTf6 MBK8dY\&t=649s) dibagi menjadi 3 kegiatan pembelajaran dengan 12 indikator yang meliputi kegiatan Pendahuluan, kegiatan inti dan kegiatan penutup.

Berdasarkan hasil penelitian dapat disarankan bahwa perlu disadari bahwa tidak ada media yang paling tepat atau paling baik untuk semua materi pembelajaran matematika demikian halnya dengan pemanfaatan program Geogebra; Untuk mendapatkan efektivitas pembelajaran matematika pada materi fungsi kuadrat maka media geogebra perlu digabung atau dikombinasikan dengan media pembelajaran yang lain, termasuk juga dengan media konvensional yang memiliki kelebihan dan keterbatasannya; dalam memanfaatkan atau menggunakan media geogebra, Guru perlu juga mempertimbangkan waktu yang paling sesuai dan tepat didalam pemanfaatan program Geogebra tersebut.

\section{DAftar Pustaka}

Aizikovitsh-Udi, E. (2011). Using Geogebra for Understanding and Supporting Students'learning of Probability. Geogebra-Na, 10.

Briggs, M., Wilkinson, C., \& Golash, A. (2014). Digital multimedia books produced using iBooks Author for pre-operative surgical patient information. Journal of visual communication in medicine, 37(3-4), 59-64.

Hendriana, H., Roharti, E. E. \& Sumarmo, U. (2017). Hard Skills dan Soft Skills Matematik Siswa. Bandung: Refika Aditama.

Hohenwarter, M. \& Fuchs, K. (2004). Combination of Dynamic Geometry, Algebra, and Calculus in the Software System Geogebra.

Tristanti, L. B. (2017). Pengaruh Model Pembelajaran Kooperatif Tipe TAI Dan Problem Based Learning (PBL) 
Terhadap Pemahaman Konsep Bangun Ruang Siswa. AKSIOMA: Jurnal Program Studi Pendidikan Matematika, 6(3), 338-349.

Tristanti, L. B., \& Rakhmawati, N. (2017). Efektifitas Model Pembelajaran Kooperatif Tipe TAl dalam Pembelajaran Geometri Dimensi Tiga. Edu Math Journal Prodi Pendidikan Matematika, 4(1).

Tristanti, L. B., \& Hidayati, W. S. (2020). The Implementation of Cooperative Learning Type Team Assisted Individualisation for Teaching 3D Geometry. Journal of Education and Learning (EduLearn), 14(2), 279-288.

Tristanti, L. B., Akbar, S., \& Rahayu, W. A. (2021). Pengaruh Media Pembelajaran Game Edukasi Berbasis Construct terhadap Kemampuan Pemecahan Masalah dan Hasil Belajar Siswa. Mosharafa: Jurnal Pendidikan Matematika, 10(1), 129-140.

Ma'rufi. (2015). Pengajuan dan Pemecahan Maslah Matematika. Bandung: Pustaka Ramadhan.

Octamela, K. S., Suweken, G., \& Ardana, I. M. (2019). Pemahaman Matematis Siswa Dengan Menggunakan Buku Elektronik Interaktif Berbantuan Geogebra. JNPM (Jurnal Nasional Pendidikan Matematika), 3(2), 305315.

Payne, K. F., Goodson, A. M., Tahim, A., Wharrad, H. J., \& Fan, K. (2012). Using the iBook in medical education and healthcare settings-the iBook as a reusable learning object; a report of the author's experience.

Purwandari, I., Ekawati, W., \& Tristanti, L.
B. (2020). Penerapan Model

Pembelajaran Problem Based Learning Dengan Media Komat Terhadap Pemecahan Masalah Dan Kecemasan Matematika Siswa. Jurnal THEOREMS (The Original Research of Mathematics), 5(1), 1-12.

Syahbana, A. (2016). Belajar Menguasai geogebra (Program Aplikasi Pembelajaran Matematika). Palembang: NoerFikri Offset.

\section{Riwayat Hidup PenUlis}

Abdur Rochim, S.Pd.

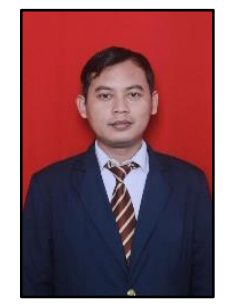

Lahir di Nganjuk pada tanggal 25 Mei 1987 dan mengabdi di SMK Muhammadiyah 1 Baron sejak tahun 2013. Pada tahun 2005 peneliti melanjutkan pendidikan di STKIP PGRI Nganjuk dan lulus pada tahun 2009. Pada tahun 2020 peneliti melanjutkan pendidikan strata dua (S2) di STKIP Jombang.

\section{Tutik Herawati, S.Pd.}

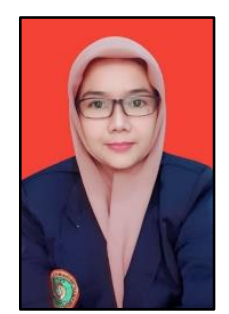
Lahir di Jombang pada tanggal 29 Juni 1984 dan mengabdi di di MI Plus darul Falah Mojoagung mulai 2019 - sekarang. Pada tahun 2002 peneliti melanjutkan pendidikan di perguruan tinggi STKIP PGRI Jombang. Peneliti menyelesaikan kuliah strata satu (S1) pada tahun 2007. Pada tahun 2020 peneliti melanjutkan pendidikan strata dua (S2) di STKIP Jombang.

\section{Dr. Nurwiani, M.Si.}

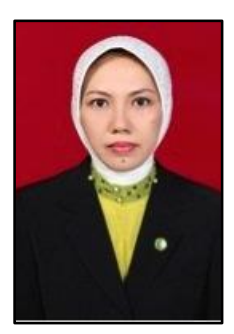

Lahir di Surabaya pada tanggal 13 Mei 1964. Berkarir sebagai dosen di STKIP PGRI Jombang hingga sekarang. Pendidikan S1 Matematika di ITS Surabaya lulus tahun 1988. Pendidikan S2 di Universitas ITS Surabaya prodi Statistika dan lulus tahun 2004. Pendidikan Program Doktor di ITS Surabaya dan lulus tahun 2015. 